\title{
Analisis Pengaruh Inflasi, Produk Domestik Bruto (PDB), dan Nilai Tukar terhadap Tabungan Mudharabah pada Bank Umum Syariah (Periode 2013-2017)
}

\author{
Rita Nur Wahyuningruma , Aan Zainul Anwar ${ }^{\mathrm{b}}$ \\ alumni Prodi Ekonomi Islam, Fakultas Ekonomi dan Bisnis, UNISNU Jepara \\ Jl. Taman Siswa, Tahunan, Jepara, Jawa Tengah, Indonesia \\ Email: ritawahyu122@gmail.com \\ ${ }^{b}$ Prodi Ekonomi Islam, Fakultas Ekonomi dan Bisnis, UNISNU Jepara \\ Jl. Taman Siswa, Tahunan, Jepara, Jawa Tengah, Indonesia \\ Email:aanza@unisnu.ac.id
}

\begin{abstract}
This study aims to analyze the effect of inflation, gross domestic product (GDP) and rupiah exchange rate on Mudharabah savings in Islamic banking in Indonesia. The data used is time series data for the period March 2013 to September 2017, which was published by Bank Indonesia from the Islamic Banking Statistics Report and the Central Statistics Agency. The technique of analyzing the research is qualitative with the method of Multiple Linear Regression. The results of this study indicate that simultaneously the Inflation, Gross Domestic Product (GDP) and Exchange Rate variables together have a significant effect on Mudharabah Savings. While partially only the Exchange Rate variable has a significant effect on Mudharabah Savings. Inflation Variables and Gross Domestic Product (GDP) have no significant effect on Mudharabah Savings.
\end{abstract}

Keyword: inflation, gross domestic product, exchange rate, mudharabah saving

\begin{abstract}
Abstrak
Penelitian ini bertujuan untuk menganalisis pengaruh inflasi, produk domestik bruto (PDB) dan nilai tukar rupiah terhadap tabungan Mudharabah pada perbankan syariah. Data yang digunakan adalah data time series periode Maret 2013 sampai dengan September 2017, yang dipublikasikan oleh Bank Indonesia dari Laporan Statistik Perbankan Syariah serta Badan Pusat Statistik (BPS). Teknik analisis penelitian kuatitiatif dengan metode Regresi Linier Berganda. Hasil dari penelitian ini menunjukkan bahwa secara simultan variabel Inflasi, Produk Domestik Bruto (PDB) dan Nilai Tukar secara bersama-sama berpengaruh signifikan terhadap Tabungan Mudharabah. Sedangkan secara parsial hanya variabel Nilai Tukar yang berpengaruh signifikan terhadap Tabungan Mudharabah. Variabel Inflasi dan Produk Domestik Bruto (PDB) tidak berpengaruh signifikan terhadap Tabungan Mudharabah.
\end{abstract}

Kata Kunci: Inflasi, Produk Domestik Bruto (PDB), Nilai Tukar, Tabungan Mudharabah.

\section{PENDAHULUAN}

Bank syariah merupakan salah satu sistem perbankan yang sedang mendapat perhatian sungguh-sungguh dari pemerintah. Hal ini disebabkan karena jenis bank syariah menjadi alternatif sistem perbankan yang berlaku di Indonesia. Sejak berlakunya UU No.7 Tahun 1992 tentang perbankan yang kemudian direvisi menjadi UU No. 10 tahun 1998 yang menyatakan industri perbankan di Indonesia terbagi menjadi bank yang beroperasi berdasarkan bunga (yang disebut bank konvensional) dan bank yang beroperasi berdasarkan bagi hasil atau sesuai dengan syariat islam disebut dengan bank syariah (Nurjannah \& Sumiyarti, 2010).

Pertumbuhan dan perkembangan bank, baik bank konvensional maupun bank syariah bisa dilihat dari semakin banyaknya jaringan kantor, aset, banyaknya produk-produk yang 
ditawarkan, dan banyaknya Dana Pihak Ketiga (DPK) yang dihimpun dari masyarakat.

DPK yang masuk ke Bank Syariah dibedakan kedalam tiga bentuk, yaitu dalam bentuk giro, tabungan, dan deposito. Produk tabungan dan deposito yang ditawarkan oleh Bank Syariah adalah dalam bentuk simpanan Mudharabah. Besarnya simpanan Mudharabah secara otomatis akan mempengaruhi besarnya DPK, oleh karena itu, mengetahui faktor-faktor yang mem-pengaruhi pergerakan simpanan Mudharabah menjadi hal yang penting (Reswari \& Abdurahim, 2010). Mudharabah merupakan akad kerja sama antara dua pihak, di mana pihak pertama menyediakan seluruh modal dan pihak lain menjadi pengelola.

Tabel 1. Komposisi Tabungan Mudharabah, Inflasi, Kurs, dan BI Rate Periode 2013-2016 di Indonesia

\begin{tabular}{ccccc}
\hline Tahun & $\begin{array}{c}\text { Tabungan } \\
\text { Mudaharabah } \\
\text { Miliar Rupiah (Rp) }\end{array}$ & $\begin{array}{c}\text { Inflasi } \\
(\%)\end{array}$ & $\begin{array}{c}\text { Nilai Tukar } \\
\text { Rupiah } \\
(\mathrm{Rp})\end{array}$ & $\begin{array}{c}\text { PDB } \\
(\%)\end{array}$ \\
\hline 2013 & 32.945 & 8,38 & 10.451 & 5,6 \\
2014 & 36.757 & 8,36 & 11.878 & 5 \\
2015 & 36.073 & 3,35 & 13.392 & 4,8 \\
2016 & 39.391 & 3,02 & 13.307 & 5 \\
\hline
\end{tabular}

Sumber: Bank Indonesia, BPS, diolah.

Dari tabel 1.1, komposisi Tabungan Mudharabah tidak terlepas dengan adanya perkembangan ekonomi di Indonesia secara makro pada tahun 2013-2016. Variabel makro tersebut seperti Inflasi, Nilai Tukar, dan PDB. Dapat dilihat pada tabel komposisi Tabungan Mudharabah dari tahun 2013 sampai 2016 mengalami peningkatan setiap tahunnya. Peningkatan ini merupakan dampak langsung dari perkembangan dari jaringan kantor dan layanan sistem perbankan syariah.

Terlihat pada tabel di atas inflasi cenderung mengalami penurunan, pada tahun 2013 sampai dengan tahun 2016, inflasi terendah terjadi pada tahun 2016. Hal tersebut disebabkan oleh penurunan daya beli masyarakat yang dipengaruhi oleh perlambatan ekonomi nasional sebagai imbas dari pelemahan ekonomi dunia.

Hasil Penelitian yang dilakukan oleh (Panorama, 2016) menunjukkan bahwa Inflasi berpengaruh negatif dan tidak signifikan terhadap Tabungan Mudharabah. Disisi lain penelitian yang dilaukan oleh (Sinaga, 2016) menunjukkan bahwa inflasi berpengaruh positif dan signifikan terhadap umlah Deposito Mudharabah.

Faktor lain yang mempengaruhi jumlah Tabungan Mudharabah adalah nilai kurs rupiah terhadap dollar AS. Data Bank Indonesia Dari tahun 2013 sampai tahun 2016 menunjukan bahwa nilai kurs jual dan kurs beli mata uang USD terhadap mata uang rupiah meningkat per tahunnya. Menurut penelitian yang dilakukan oleh (Muttaqiena, 2013) menunjukkan bahwa nilai tukar berpengaruh terhadap Dana Pihak Ketiga. Sedangkan menurut (Iskandar \& Firdaus, 2014) menunjukkan bahwa nilai tukar tidak berpengaruh terhadap deposito Mudharabah.

Penelitian yang dilakukan oleh (Nurjannah \& Sumiyarti, 2010) menunjukkan bahwa Produk Domestik Bruto (PDB) berpengaruh positif dan signifikan tehadap simpanan Mudharabah. Namun menurut penelitian yang dilakukan oleh (Ali, Hassan, \& kasim, 2012) menunjukkan bahwa produk domestik bruto (PDB) tidak berpengaruh terhadap Deposito Mudharabah. Berdasarkan latar belakang di atas, maka peneliti tertarik untuk meneliti lebih lanjut, dalam penelitian ini variabel makro yang akan digunakan adalah inflasi, nilai tukar (kurs), dan Produk Domestik Bruto (PDB) yang berpengaruh terhadap Tabungan Mudharabah pada perbankan syariah di Indonesia dengan periode tahun 2013 sampai dengan tahun 2017.

\section{KAJIAN LITERATUR DAN PENGEMBANGAN HIPOTESIS Pengertian Bank Syariah}

Perkembangan bank syariah di berbagai negara Islam lainnya memberikan dampak pengaruh yang positif bagi perkembangan bank syariah di Indonesia. Bank syariah ini memiliki sistem operasional yang berbeda dengan bank konvensional. Bank syariah adalah bank yang memberikan layanan bebas bunga kepada para nasabahnya. Dalam sistem operasional bank syariah, tidak ada transaksi pembayaran maupun penarikan dalam bentuk bunga (riba). Bank syariah tidak mengenal sistem bunga, baik bunga yang diperoleh dari nasabah yang meminjam uang atau bunga 
yang dibayar kepada penyimpan dana di bank syariah (Ismail 2011).

Bank syariah di Indonesia yang pertama didirikan pada tahun 1992 yaitu Bank Muamalat Indonesia (BMI). Walaupun perkembangannya agak terlambat bila dibandingkan dengan Negara-negara muslim lainnya, perbankan syariah di Indonesia akan terus berkembang. Bila pada periode tahun 1992-1998 hanya ada satu unit bank syariah. Maka pada tahun 2005, jumlah bank syariah di Indonesia telah bertambah menjadi 20 unit, yaitu 3 bank umum syariah dan 17 unit usaha syariah. Sementara itu, jumlah bank perkreditan rakyat syariah (BPRS) hingga akhir tahun 2004 bertambah menjadi 88 buah (Karim, 2013).

\section{Sumber Dana Bank Syariah}

Pada dasarnya, dilihat dari sumbernya dana bank syariah terdiri atas (Antonio, 2001):

\section{Modal}

Modal adalah dana yang diserahkan oleh para pemilik (owner). Pada akhir periode tahun buku, setelah dihitung keuntungan yang didapat pada tahun tersebut, pemilik modal akan memperoleh bagian dari hasil usaha yang biasa dikenal dengan deviden.

\section{Titipan}

Salah satu prinsip yang digunakan bank syariah dalam memobilisasi dana adalah dengan menggunakan prinsip titipan. Adapun akad yang sesuai dengan prinsip ini adalah alwad'iah. Al-wad'iah merupakan titipan murni yang setiap saat dapat diambil jika pemiliknya menghendaki.

\section{Investasi}

Prinsip lain yang digunakan adalah prinsip investasi. Akad yang sesuai dengan prinsip ini adalah Mudharabah. Tujuan dari Mudharabah adalah kerja sama antara pemilik dana (shahibul maal) dan pengelola dana (mudharib), dalam hal ini bank

\section{Tabungan Mudharabah}

Tabungan adalah simpanan berdasarkan akad wadiah (titipan), bagi hasil (Mudharabah) atau dengan akad lainnya yang tidak bertentangan dengan prinsip-prinsip Islam.
Penarikan uang tersebut hanya dapat dilakukan menurut syatar-syarat dan ketentuan tertentu (Antonio, 2001).

Mudharabah berasal dari kata dharb, berarti memukul atau berjalan. Pengertian memukul atau berjalan ini lebih tepatnya adalah proses seseorang memukulkan kakinya dalam menjalankan usaha. Secara teknis Akad Mudharabah adalah akad perjanjian antara dua pihak atau lebih untuk melakukan kerja sama usaha. Satu pihak menempatkan modal sebesar $100 \%$ yang disebut dengan shahibul maal, dan pihak lainnya sebagai pengelola usaha yang disebut dengan mudharib.

Keuntungan usaha secara Mudharabah dibagi menurut kesepakatan yang dituangkan dalam kontrak, sedangkan apabila rugi ditanggung oleh pemilik modal selama kerugian itu bukan akibat kelalaian si pengelola dana. Seandainya kerugian itu diakibatkan karena kecurangan atau kelalaian pengelola, maka pengelola harus bertanggung jawab atas kerugian tersebut.

\section{Jenis-Jenis al-Mudharabah}

Secara umum, Mudharabah terbagi menjadi dua jenis, yaitu:

\section{Mudharabah Muthlaqah}

Yang dimaksud dengan transaksi Mudharabah muthlaqah adalah bentuk kerja sama antara sahibul maal dan mudharib yang cakupannya sangat luas dan tidak dibatasi oleh spesifikasi jenis usaha, waktu, dan daerah bisnis. Dalam pembahasan fiqh ulama salafus saleh seringkali dicontohkan dengan ungkapan if'al ma syi'ta (lakukan sesukamu) dari shahibul maal ke mudharib yang memberi kekuasaan sangat besar.

\section{Mudharabah Muqayyadah}

Mudharabah Muqayyadah atau disebut juga dengan istilah restricted Mudharabah/ specified Mudharabah adalah kebalikan dari Mudharabah muthlaqah. Si mudharib dibatasi dengan batasan jenis usaha, waktu, atau tempat usaha, jenis investasi, tempat investasi, serta pihak-pihak yang dibolehkan terlibat dalam investasi. Adanya pembatasan ini seringkali mencerminkan kecenderungan umum si shahibul maal dalam memasuki dunia usaha. 


\section{Tingkat Inflasi}

Inflasi adalah kecenderungan dari hargaharga untuk menarik secara terus menerus. Kenaikan dari satu atau dua jenis barang saja tidak bisa disebut inflasi, kecuali bila kenaikan tersebut meluas atau menyebabkan kenaikan sebagian besar dari harga barang-barang lain, kenaikan harga secara musiman juga penyebab inflasi. Kenaikan harga secara musiman, mislanya menjelang lebaran, natal dan tahun baru atau baru terjadi sekali saja, serta tidak pengaruh lanjutan, tidak dianggap sebagian suatu penyakit ekonomi yang memerlukan penanganan khusus untuk menanggulanginya (Abdullah \& Tantri, 2012).

Inflasi merupakan peningkatan hargaharga secara umum dan terus menerus. Apabila terjadi inflasi maka terjadi ketidakpastian kondisi makroekonomi suatu negara, adanya ketidakpastian kondisi perekonomian suatu negara akan mengakibatkan masyarakat lebih menggunakan dananya untuk konsumsi. Tingginya harga dan pendapatan yang tetap atau pendapatan meningkat sesuai dengan besarnya inflasi membuat masyarakat tidak mempunyai kelebihan dana untuk disimpan atau diinvestasikan.

\section{Produk Domestik Bruto}

Produk Domestik Bruto (PDB) adalah nilai barang dan jasa yang diproduksi oleh suatu negara dalam suatu periode tertentu yang menjumlahkan semua hasil dari warga negara yang bersangkutan ditambah warga negara asing yang bekerja di negara yang bersangkutan (Putong, 2002). Faktor PDB diperhitungkan untuk mewakili tingkat pendapatan atau kegiatan ekonomi. Hal ini berkaitan bahwa tingkat pendapatan menggambarkan kemampuan masyarakat untuk menabung, dalam teori Keynes semakin tinggi pendapatan, maka akan tinggi pertumbuhan tabungan $M u$ dharabah pada bank syariah.

\section{Nilai Tukar Rupiah}

Exchange Rate (nilai tukar) atau yang lebih populer dikenal dengan nama kurs mata uang adalah catatan (quotation) harga pasar dari mata uang asing (foreign currency) dalam harga mata uang domestik (domestic currency), atau mata uang domestik dalam mata uang asing. Nilai tukar uang menggambarkan tingkat harga pertukaran dari satu mata uang kemata uang yang lainnya dan digunakan dalam berbagai transaksi, antara lain transaksi perdagangan internasional, ataupun aturan uang jangka pendek antar negara yang melewati batasbatas geografis ataupun batas-batas hukum (Karim A. A., 2007).

Kurs merupakan faktor eksternal (luar) yang juga mempengaruhi jumlah dana pihak ketiga. Melemahnya nilai tukar rupiah terhadap dollar AS, mencerminkan kondisi perekonomian yang tidak menentu sehingga meningkatkan risiko berusaha yang akan direspon oleh dunia usaha dengan menitipkan uangnya pada bank syariah.

\section{Kerangka Pemikiran Teoritis}

Berdasarkan tinjauan pustaka dan penelitian terdahulu, maka pengaruh Inflasi, Produk Domesik Bruto (PDB) dan Nilai Tukar Terhadap Tabungan Mudharabah dapat digambarkan sebagai berikut:

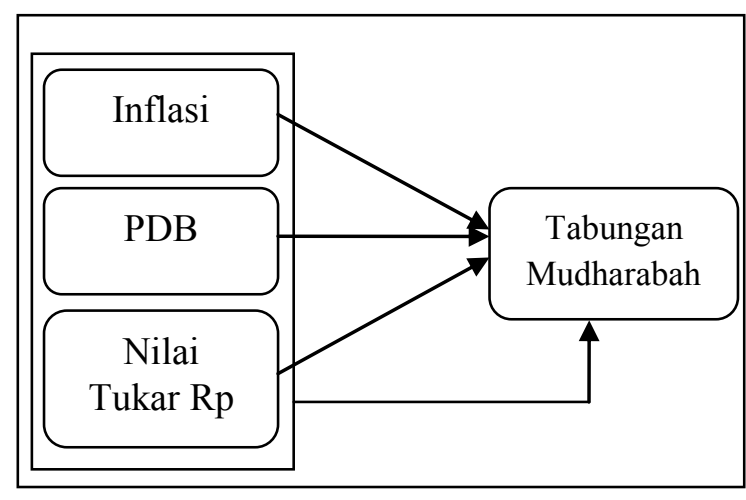

Gambar 1. Kerangka Pemikiran

\section{Perumusan Hipotesis}

Berdasarkan rumusan kerangka penelitian diatas tersebut hipotesis yang diajukan dalam penelitian ini adalah:

H1: Inflasi berpengaruh terhadap Tabungan Mudharabah Pada Perbankan Syariah.

H2: Produk Domestik Bruto (PDB) berpengaruh terhadap Tabungan Mudharabah Pada Perbankan Syariah.

H3: Nilai Tukar berpengaruh terhadap Tabungan Mudharabah Pada Perbankan Syariah.

H4: Inflasi, Produk Domestik Bruto (PDB) dan Nilai Tukar secara bersama-sama 
berpengaruh terhadap Tabungan Mudharabah Pada Perbankan Syariah.

\section{METODE PENELITIAN}

Penelitian ini termasuk penelitian kuantitatif dengan data runtut waktu (Time Series) yaitu analisis data dalam bentuk angkaangka dalam pembahasannya. Sumber data pada penelitian ini dikumpulkan dengan menggunakan data sekunder berupa laporan keuangan yang dipublikasi. Jumlah populasi dalam penelitian ini adalah 11 Bank Umum Syariah. Cara pengambilan sampel dengan teknik purposive sampling adalah penarikan sample yang dilakukan dengan cara memilih sample berdasarkan kriteria yang di tetapkan peneliti (Sugiyono, 2011).Sehingga didapatkan sampel 4 Bank Umum Syariah yaitu Bank Muamalat, Bank Syariah Mandiri, Bank Syariah Mega Indonesia, dan Bank BNI Syariah. Serta laporan keuangan BankSyariah tersebut selama periode januari 2013 sampai dengan oktober 2017 dengan laporan publikasi pertriwulan.

Teknik analisis data yang dilakukan pada penelitian ini adalah sebagai berikut: 1) Perhitungan variabel dependen dan variabel independen, 2) Uji Normalitas, 3) Uji Asumsi Klasik, 4) Analisis regresi berganda, 5) Uji hipotesis simultan $(\mathrm{F})$ dan parsial (t), dan 6) Koefisien determinasi $\left(R^{2}\right)$.

\section{HASIL DAN PEMBAHASAN \\ Uji Asumsi klasik \\ Uji Normalitas}

Uji normalitas bertujuan untuk menguji apakah dalam model regresi, variabel terikat atau variabel bebas memiliki distribusi normal (Ghozali, 2013). Uji kenormalan data dilakukan berdasarkan dengan uji Kolmogrof-Smirnov. Cara mendeteksi yaitu dengan menggunakan histogram regression residual yang sudah distandarkan serta menggunakan analisis kai kuadrat $\left(\mathrm{X}^{2}\right)$ dan kormoglov-smirnov. Kurva nila residual terstandarisasi dikatakan menyebar dengan normal apabila: nilai kormoglov-smirnov $\mathrm{Z} \leq \mathrm{Z}$ tabel, atau nilai asymp. Sig. $(2-$ tailed $)>\mathrm{a}$ (alpha). Apabila nilai asymp. Sig. > 0,05 (alpha), maka nila residual terstandarisasi dikatakan menyebar secara normal (Suliyanto, 2005).

Hasil uji normalitas dalam penelitian ini dapat dilihat pada gambar 4.1
Tabel 2. Hasil Uji Normalitas

One-Sample Kolmogorov-Smirnov Test

\begin{tabular}{llr}
\hline & & \multicolumn{2}{c}{$\begin{array}{c}\text { Unstandardized } \\
\text { Residual }\end{array}$} \\
\hline $\mathrm{N}$ & & 41 \\
Normal & Mean & $-508598,4056465$ \\
Parameters ${ }^{\mathrm{a}, \mathrm{b}}$ & Std. Deviation & 4399556,11111343 \\
Most & Absolute &, 084 \\
Extreme & Positive &, 084 \\
Differences & Negative &,- 062 \\
Kolmogorov-Smirnov Z &, 535 \\
Asymp. Sig. (2-tailed) &, 937 \\
\hline a. Test distribution is Normal. & \\
b. Calculated from data. &
\end{tabular}

Sumber data: Output SPSS, 2018.

Dari hasil uji normalitas menggunakan uji Kormoglov-Smirnov menunjukkan bahwa nilai Asymp. Sig. (2-tailed) sebesar 0,937 dan signifikan pada 0,05 . Hal ini menunjukkan bahwa nilai signifikan $0,937>0,05$, berarti dapat disimpulkan bahwa data berdistribusi normal.

\section{Uji Multikolonieritas}

Untuk mengetahui ada tidaknya variabel independent yang memiliki kemiripan antar variabel independent dalam satu model. Kemiripan antar variabel independent akan mendapatkan kolerasi yang sangat kuat. Selain itu juga untuk menghindari kebiasaan dalam proses pengambilan keputusan mengenai pengaruh pada uji parsial masing-masing variabel independen terhadap variabel dependen. Jika variance inflasion factor (VIF) yang dihasilkan diantara 1 sampai 10 maka tidak terjadi multikolinieritas (Sujarweni, 2007).

Hasil uji multikolinieritas untuk model regresi pada penelitian ini disajikan pada tabel 2.

Tabel 3. Hasil Uji Multikololinearitas

\begin{tabular}{lccc}
\hline \multirow{2}{*}{ Variabel } & \multicolumn{2}{c}{ Collinearity Statistics } & \multirow{2}{*}{ Keterangan } \\
\cline { 2 - 3 } & Tolerance & VIF & \\
\hline Inflasi $(X 1)$ & 0,675 & 1,481 & Tidak terjadi \\
PDB (X2) & 0,944 & 1,059 & Tidak terjadi \\
Nilai Tukar $(X 3)$ & 0,708 & 1,412 & Tidak terjadi \\
\hline
\end{tabular}

Sumber data: Output SPSS, 2018. 
Dari tabel 4 terlihat bahwa nilai tolerance Inflasi (X1), Produk Domestik Bruto (X2), dan Nilai Tukar (X3) diatas 0,10 dan nilai VIF berada dibawah 10 sehingga dapat disimpulkan bahwa tidak terjadi multikolonieritas.

\section{a. Uji Heterokedastisitas}

Uji heteroskedastisitas bertujuan untuk menguji apakah dalam sebuah model regresi terjadi ketidaksamaan variance dari residual satu pengamatan ke pengamatan yang lain (Ghozali, 2013). Cara untuk mendeteksi ada atau tidaknya heterokedastisitas, yaitu jika ada pola tertentu seperti titik-titik yang ada membentuk pola tertentu yang teratur (bergelombang, melebar maupun kemudian menyempit), maka terjadi heterokedastisitas. Dan jika tidak ada pola yang jelas, serta titik menyebar diatas dan dibawah angka 0 pada sumbu Y, maka tidak terjadi heterokedastisitas. Hasil uji heterokedastisitas sebagai berikut:

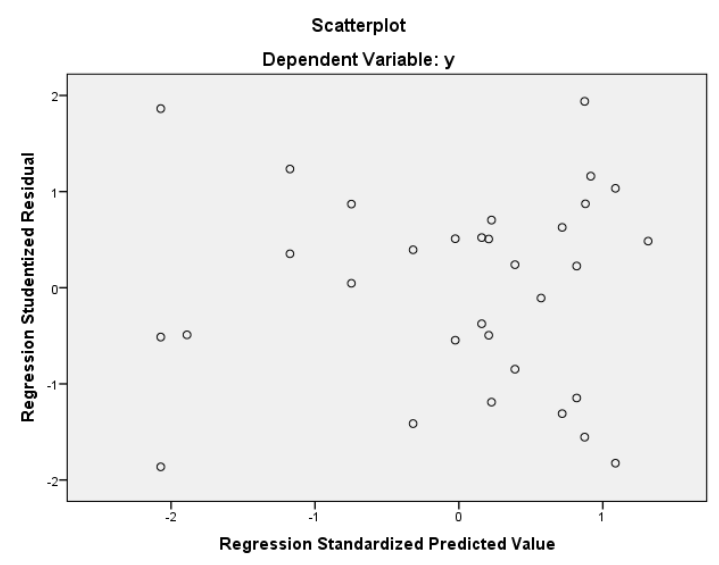

Gambar 2. Uji Heterokedastisitas

Sumber data: Output SPSS, 2018.

Pada gambar diatas menunjukkan bahwa tidak terdapat pola yang jelas, serta titiktitiknya menyebar diatas dan dibawah angka 0 pada sumbu $Y$, sehingga dapat disimpulkan bahwa dalam penelitia ini bebas dari uji heterokedastisitas.

\section{b. Uji Autokorelasi}

Uji autokorelasi digunakan untuk mengidentifikasi apakah ada korelasi antara anggota serangkaian observasi yang diuraikan menurut waktu (Time Series) atau ruang (cross section) (Suliyanto, 2005). Untuk mendeteksi ada atau tidaknya autokorelasi yaitu menggunakan uji Durbin-Watson (DW) dengan kriteria nilai $\mathrm{dU}<\mathrm{DW}<4-\mathrm{dU}$. Berikut hasil uji autokorelasi:

Dari tabel Durbin-Watson dengan tingkat signifika $5 \%$, dengan $\mathrm{N}$ sebesar 32 diketahui bahwa dL sebesar 1,651 dU sebesar 1,243 dan 4 - dU $(4-1,651)$ sebesar 2,3489. Adapun hasil perhitungan Durbin-Watson sebesar 1,745. Nilai DW ini berada pada daerah $\mathrm{dU}<\mathrm{DW}<$ 4 - dU yakni 1,651 < 1,745 < 2,3489 sehingga dapat disimpulkan dahwa data tersebut bebas problem autokorelasi.

\section{Analisis Regresi Linier Berganda}

Analisis regresi linier berganda dlaa penelitian ini digunakan untuk menyatakan hubungan antara varibel dependen (terikat) da variabel independen (bebas). Berikut ini adalah hasil uji rgresi linier berganda dengan spss dan selnjutnya akan kedalam persamaan regresi linier berganda untuk dianalisis.

Tabel 4. Uji Regresi Linier Berganda

\begin{tabular}{llrr}
\hline \multirow{2}{*}{ Model } & \multicolumn{2}{c}{ Unstandardized Coefficients } \\
\cline { 3 - 4 } & (Constant) & \multicolumn{1}{c}{ B } & \multicolumn{1}{c}{ Std. Error } \\
\hline \multirow{3}{*}{1} & X1_- & 70672232,425 & 16100898,871 \\
& X2 & $-11,278$ & 490814,988 \\
& X3 & $-2324480,508$ & 8,052 \\
\hline
\end{tabular}

Sumber data: Output SPSS, 2018.

Dengan hasil perhitungan regresi linier berganda pada tabel diatas dapat diketahui hubungan antar variabel independen dan variabel dependen yang dapat dirumuskan dalam persamaan sebagai berikut:

$$
\begin{aligned}
& Y=45572232,425+706996,797 X_{1}-11,278 X_{2} \\
& -2324480,508 X_{3}+e
\end{aligned}
$$

Pada persamaan diatas ditunjukka pengaruh varibael indpenden $(X)$ terhadap variabel dependen $(\mathrm{Y})$, adapun arti dari koefisien regresi tersebut adalah:

a. Konstanta (B) $=45572232,425$

Artinya, apabila Inflasi, Produk Domestik Bruto (PDB) dan Nilai Tukar sama dengan nol maka Tabungan Mudharabah pada Bank Umum Syariah sebesar 45572232,425.

b. Koefisien Inflasi $\left(X_{1}\right)=706996,797$ 
Artinya, apabila kenaikan Inflasi sebesar 1 persen, maka Tabungan Mudharabah pada Bank Umum Syariah akan mengalami kenaikan sebesar 706996,797 dengna asumsi variabel lain adalah konstan.

c. Koefisisen PDB $\left(X_{2}\right)=-11,278$

Artinya, apabila kenaikan Produk Domestik Bruto (PDB) sebesar 1 persen, maka Tabunga Mudharabah pada Bank Umum Syariah akan mengalami penurunan sebesar 11,278 dengan asumsi variabel lain adalah konstan.

d. Koefisien Nilai Tukar $\left(X_{3}\right)=-2324480,508$ Artinya, apabila kenaikan Nilai Tukar rupiah sebesar 1 persen, maka Taunga Mudharabah pada Bank Umum Syariah akan mengalami penurunan sebesar 2324480,508 dengan asumsi variabel lain adalah konstan.

\section{Uji Hipotesis \\ Uji $t$}

Uji ini digunakan untuk mengetahui apakah masing-masing variabel independen secara sendiri-sendiri mempunyai pengaruh secara signifikan terhadap variabel dependen.

Untuk mengkaji pengaruh variabel independen terhadap dependen secara individu dapat dilihat hipotesis berikut: Nilai signifikan (alpha) yang digunakan yaitu sebesar 5\% atau 0,05 . Apabila nilai signifikan $<0,05$ maka signifikan (variabel $X$ berpengaruh signifikan terhadap variabel $Y$ ) dan jika nilai signifikan $>0,05$ maka tidak signifikan (variabel $X$ tidak berpengaruh signifikan terhadap variabel $\mathrm{Y}$ ). Uji t digunakan untuk membuat keputusan apakah hasil hipotesis terbukti atau tidak (Suliyanto, 2005).

Tabel 5. Regression Calculation

\begin{tabular}{rlrr}
\multicolumn{4}{c}{ Coefficients $^{\mathrm{a}}$} \\
\hline Model & & $\mathrm{t}$ & \multicolumn{1}{c}{ Sig. } \\
\hline \multirow{4}{*}{1} & (Constant) & 2,830 &, 007 \\
& X1_ & 1,440 &, 157 \\
& X2 & $-1,863$ &, 070 \\
& X3 & $-2,868$ &, 006 \\
\hline
\end{tabular}

a. Dependent Variable: $Y$

Sumber : Output SPSS, data diolah 2018

a. Pengujian pengaruh variabel Inflasi (X1) terhadap variabel Tabungan Mudharabah (Y)
Pada tabel diatas diperoleh hasil dengan nilai signifikan variabel inflasi sebesar 0,157 . Nilai signifikan (alpha) yang digunakan sebesar 0,05. Dari hasil tersebut diketahui bahwa nilai signifikan 0,157 > 0,05 sehingga dapat disimpulkan bahwa variabel inflasi tidak berpengaruh secara signifikan terhadap Tabungan Mudharabah dan Ha ditolak.

b. Pengujian pengaruh variabel PDB (X2) terhadap variabel Tabungan Mudharabah $(\mathrm{Y})$ Pada tabel diatas diperoleh hasil dengan nilai signifikan variabel PDB sebesar 0,70. Nilai signifikan (alpha) yang digunakan sebesar 0,05. Dari hasil tersebut diketahui bahwa nilai signifikan $0,70>0,05$ sehingga dapat disimpulkan bahwa variabel Produk Domestik Bruto (PDB) tidak berpengaruh secara signifikan terhadap Tabungan Mudharabah dan Ha ditolak.

c. Pengujian pengaruh variabel Nilai Tukar (X3) terhadap variabel Tabungan Mudharabah (Y)

Pada tabel diatas diperoleh hasil dengan nilai signifikan variabel Nilai Tukar sebesar 0,006. Nilai signifikan (alpha) yang digunakan sebesar 0,05. Dari hasil pengujian diketahui bahwa nilai signifikan 0,006 $<0,05$ sehingga dapat disimpulkan bahwa variabel Nilai Tukar berpengaruh secara signifikan terhadap Tabungan Mudharabah dan Ha diterima.

\section{Uji F}

Uji F digunakan untuk apakah keseluruhan variabel independen berpengaruh terhadap variabel dependen dengan menggunakan signisikan (alpha) 5\% atau 0,05 kriteria pengujiannya apabila nilai signifikan $<$ alpha 0,05 maka secara simultan variabel independen yang digunakan berpengaruh signifika terhadap variabel dependen. Apabila nilai signifikan > alpha 0,05 maka secara simultan variabel independen tidak berpengaruh signifikan terhadap variabel dependen (Suliyanto, 2005).

\section{Tabel 6. Uji SImultan}

\begin{tabular}{lllll}
\multicolumn{9}{c}{ ANOVA $^{\text {a }}$} \\
\hline Model & df & Mean Square & F & Sig. \\
\hline
\end{tabular}




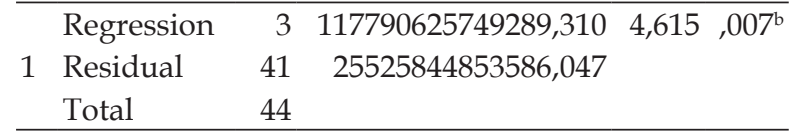

a. Dependent Variable: $Y$

b. Predictors: (Constant), X3_Ln, X2, X1_Lag

Sumber : Output SPSS, data diolah 2018

Pada tabel diatas diperoleh hasil nilai signifikan F sebesar 0,007 dan tingkat kriteria signifikan (alpha) 0,05. Nilai signifikan 0,007 $<$ 0,05 maka dapat disimpulkan bahwa secara simultan variabel Inflasi, Produk Domestik Bruto (PDB) dan Nilai Tukar berpengaruh signifikan terhadap variabel Tabunga Mudharabah, dan Ha diterima.

\section{Koefisien Determinasi $\left(\mathbf{R}^{2}\right)$}

Berdasarkan hasil analisis dengan SPSS diperoleh data sebagai berikut ditunjukkan pada tabel 4.13 dibawah ini:

Tabel 7. Determination Coefficient test

\begin{tabular}{|c|c|c|c|c|}
\hline \multicolumn{5}{|c|}{ Model Summary ${ }^{b}$} \\
\hline Model & $\mathrm{R}$ & R Square & $\begin{array}{l}\text { Adjusted } \\
\text { R Square }\end{array}$ & $\begin{array}{l}\text { Std. Error of the } \\
\text { Estimate }\end{array}$ \\
\hline 1 & $502^{\mathrm{a}}$ & ,252 & 198 & 5052310,843 \\
\hline
\end{tabular}

Sumber : Output SPSS, data diolah 2018

Dari tabel tersebut dapat diketahui bahwa hasil nilai Adjusted R Square sebesar 0,198 atau $19,8 \%$ artinya variabel dependen (Y) dalam model yaitu pergerakan Tabungan Mudharabah dijelaskan oleh variabel independen yaitu tingkat Inflasi, Produk Domestik Bruto (PDB) dan Nilai Tukar sebesar $19,8 \%$, sedangkan sisanya $80,2 \%$ dijelaskan oleh faktor lain di luar model.

\section{PEMBAHASAN}

\section{Pengaruh Inflasi terhadap Tabungan Mudharabah}

Berdasarkan analisis data dan pengujian hipotesis yang telah dilakukan dalam penelitian ini, dapat diketahui bahwa Inflasi terbukti tidak berpengaruh signifikan terhadap Tabungan Mudharabah. Hasil penelitian ini mendukung penelitian yang dilakukan Faisal Affandi (2016), dimana disebutkan bahwa secara parsial variabel Inflasi tidak berpengaruh signifikan terhadap margin bagi hasil deposito
Mudharabah perbakan syariah di Indonesia periode 2010-2015. Hasil menunjukka bahwa semakin besar inflasi maka semakin kecil margin bagi hasil Mudharabah.

Hasil penelitian ini menunjukkan bahwa inflasi tidak berpengaruh signifikan terhadap tabungan Mudharabah dengan nilai sig. yaitu 0,157. Nasabah Bank Syariah sepertinya sudah terbiasa dengan tingkat inflasi yang terjadi di Indonesia, sehingga sudah direncanakan alokasi dana yang digunakan untuk konsumsi dan dana untuk simpanan maupun investasi. Nasabah Bank Syariah tidak terpengaruh oleh fluktuasi tingkat inflasi di Indonesia dan bisa juga disebabkan oleh naik turnnnya inflasi di Indonesia sehingga mereka kesulitan untuk memilih investasi selain deposito karena investasi ditempat lain kemungkinan akan memiliki risiko yang lebih tinggi.

\section{Pengaruh Produk Domestik Bruto Terhadap Tabungan Mudharabah}

Berdasarkan analisis data dan pengujian hipotesis yang telah dilakukan dalam penelitian ini, dapat diketahui bahwa Produk Domestik Bruto (PDB) terbukti tidak berpengaruh signifikan terhadap Tabungan Mudharabah. Hasil penelitian ini berbeda dengan penelitianpenelitian terdahulu, yang menunjukkan bahwa terdapat pengaruh signifikan antara variabel PDB terhadap Tabungan Mudharabah.

Berbeda dengan hasil penelitian ini yang menunjukkan bahwa variabel PDB tidak berpengaruh signifikan terhadap Tabungan Mudharabah dengan nilai sig. sebesar 0,70 . Setiap pendapatan yang diterima masyarakat meningkat mereka memilih untuk tidak menambah atau mengurangi jumlah tabungannya. Namun, masyarakat lebih menggunakan dananya untuk konsumsi.

Dan pada tahun 2016, nasabah atau masyarakat lebih memilih mengambil membayar angsuran pembiayaan daripada tabungan terbukti dengan pada beberapa bank umum syariah jumlah pembiayaannya lebih tinggi dari simpanan. Seperti halnya masyarakat di Jepara yaitu jika pendapatan mereka itu tinggi maka pendapatan yang diterima akan dibuat untuk membeli keperluankeperluan konsumtif mereka dan memilih mengajukan pembiayaan untuk membeli 
keperluan konsumtif mereka daripada untuk berjaga-jaga atau simpanan.

\section{Pengaruh Nilai Tukar Terhadap Tabungan Mudharabah}

Berdasarkan analisis data dan pengujian hipotesis yang telah dilakukan dalam penelitian ini, dapat diketahui bahwa Nilai Tukar terbukti berpengaruh signifikan terhadap Tabungan Mudharabah dengan nilai sig. sebesar 0,006. Hasil penelitian ini mendukung penelitian yang dilakukan oleh Dian Iskadar dan Iwan Firdaus (2014) dimana disebutkan bahwa secara parsial Nilai Tukar berpengaruh signifikan negatif terhadap Deposito Mudharabah. Jika nilai tukar rupiah melemah terhadap dollar maka akan berdampak terhadap daya beli masyarakat menjadi turun sehingga masyarakat akan menarik uang dari bank untuk memenuhi kebutuhan konsumsinya.

Perbankan syariah rentan terhadap perubahan nilai tukar rupiah, jika nilai rupiah melemah, DPK perbankan syariah salah satunya tabungan Mudharabah juga akan menurun. Ini sesuai dengan teori, dimana baik nasabah korporasi maupun individu akan cenderung menarik dana-dananya dari perbankan syariah jika nilai tukar rupiah tersebut melemah.

\section{Pengaruh Inflasi, Produk Domestik Bruto (PDB) dan Nilai Tukar secara bersama-sama Terhadap Tabungan Mudharabah}

Berdasarkan analisis data dan pengujian hipotesis yang telah dilakukan dalam penelitian ini, dapat diketahui bahwa secara bersama-sama (simultan) variabel Inflasi, Produk Domestik Bruto (PDB) dan Nilai Tukar secara bersamasama berpengaruh signifikan terhadap Tabungan Mudharabah dengan nilai sig. sebesar 0,007.

\section{KESIMPULAN}

Berdasarkan hasil penelitian regresi linier berganda mengenai pengaruh inflasi, produk domestik bruto (PDB) dan nilai tukar terhadap tabungan Mudharabah yang telah dilakukan oleh penelitii pada bab sebelumnya, maka peneliti mengambil kesimpulan dari penelitian yang dilakukan tersebut yaitu pengujian secara individu (parsial) variabel inflasi dan produk domestik bruto (PDB) tidak berpengaruh signifikan terhadap Tabungan Mudharabah. Dan secara individu (parsial) variabel nilai tukar berpengaruh signifikan terhadap Tabungan Mudharabah. Serta berdasarkan pengujian secara simultan variabel independen (inflasi, produk domestik bruto (PDB) dan nilai tukar secara bersma-sama mempunya pengaruh signifikan terhadap variabel dependen (Tabungan Mudharabah).

\section{DAFTAR PUSTAKA}

Abdullah, T., \& Tantri, F. (2012). Bank dan Lembaga Keuangan. Jakarta: PT Raja Grafindo Persada.

Ali, S., Hassan, A. A., \& kasim, K. (2012). Macroeconomic Variabels and Its Impact To Mudharabah Investment Deposits In Malaysia. Elixir International Journal ,1086610869.

Antonio, M. S. (2001). Bank Syariah: dari Teorike Praktek. Yogyakarta : UGM Press.

Ghozali, P. (2013). Aplikasi Analisis Multivariate Dengan Program IBM SPSS 21 Update PLS Regresi. Semarang: Badan Penerbit Universitas Diponegoro.

Ismail, D. (2011). Perbankan Syariah. Jakarta: Kencana Prenadamedia Group.

Karim, A.A. (2013). Bank Islam Analisis Fiqih dan Keuangan. Jakarta: PT Raja Grafindo Persada.

Muttaqiena, A. (2013). Analisis Pengaruh PDB, Inflasi, Tingkat Bunga, dan nilai Tukar Terhadap Dana Pihak Ketiga Perbankan Syariah di Indonesia 2008-2012. Economics Development Analysis, Vol. 2.

Nurjannah, \& Sumiyarti. (2010). Pengaruh Nisbah Bagi Hasil, Produk Domestik Bruto, Suku Bunga Deposito dan Inflasi Terhadap Simpanan Mudharabah di Perbankan Syariah Indonesia Periode 2004-2009. Media Ekonomi, Vol. 18 No. 1.

Panorama, M. (2016). Pengaruh Pertumbuhan Ekonomi, Inflasi, Jumlah Uang Beredar (M2) Dan Bi Rate Terhadap Tabungan Mudharabah Pada Perbankan Syariah. I-Economic , Vol. 1 no. 1.

Putong, I. (2002). Pengantar Ekonomi Mikro \& Makro. Jakarta: Ghalia Indonesia.

Reswari, Y. A., \& Abdurahim, A. (2010). Pengruh Tingkat Suku Bunga, Jumlah Bai Hasil dan LQ 45 Terhadap Simpanan 
Mudharabah. Akuntansi dan Investasi, Vol. 11 No. 1 hlm. 30-41.

Sinaga, A. (2016). Analisis Pengaruh Tingkat Suku Bunga (BI Rate), Bagi Hasil, Inflasi dan Harga Emas Terhadap Jumlah Deposito Mudharabah. Analityca Islamica, Vol. 5: 315341.
Sugiyono. (2011). Metode Penelitian Adminstrasi. Bandung: Alfabeta.

Sujarweni, V. W. (2007). SPSS Untuk penelitian Skripsi, Tesis, Desertasi dan Umum. Yogyakarta: Ardana Media.

Suliyanto. (2005). Analisis Data Dalam Aplikasi Pemasaran. Bogor: Ghalia Indonesia. 